\title{
UJI KANDUNGAN FITOKIMIA DAN ETNOBOTANI TUMBUHAN OBAT TRADISIONAL BERBASIS PENGETAHUANLOKAL DI KECEMATAN LAMBITU KABUPATEN BIMA
}

\author{
Nikman Azmin*1, Anita Rahmawati², M. Eka Hidayatullah ${ }^{3}$ \\ ${ }^{1.2}$ Sekolah Tinggi Keguran dan Ilmu Pendidikan (STKIP) Bima \\ ${ }^{3}$ UNS (Universitas Sebelas Maret) Surakarta \\ Author correspondent: biologinikman@gmail.com
}

Diterima 11 September 2019, Disetujui 2 Oktober 2019

\begin{abstract}
This study aims to study the collection and use of traditional plants by the Bima community. The method used is in-depth interviews, field surveys and questionnaire techniques. Maseration and phytochemical screening tests were carried out to determine the content of active compounds in traditional plants. The results of this study indicate that the types of traditional medicinal plants used as phytochemical test samples consist of 19 types of traditional medicinal plants. Parts of medicinal plants used as raw materials that have medicinal properties in the form of leaves $40 \%$, rhizomes $28 \%$, Fruit $12 \%$, stem $8 \%$, roots \%, sap or lenders $4 \%$. Phytochemical test results show that the compounds contained in medicinal plants are Flavonoids, Alkaloids, Steroids, Terpenoids, Saponins and Tanins. Generally Bima people manage and utilize various types of medicinal plants, such as trees, shrubs, herbs and weeds as ingredients (herbs) in the treatment of various diseases.
\end{abstract}

Keywords: Phytochemicals, Ethnobotany, Traditional Medicinal Plants, Local Wisdom

\section{PENDAHULUAN}

Penggunaan tumbuhan obat tradisional masih sangat terbatas, sedangkan Indonesia memiliki potensi tumbuhan obat sangat besar, sebanyak 30.000 jenis dari total 40.000 jenis tumbuhan dunia. Baru sebanyak 940 jenis diantaranya telah dinyatakan berkhasiat sebagai obat,atau sekitar $80 \%$ dari seluruh tumbuhan obat yang ada di Benua Asia telah dilakukan uji klinis. Dari sekian banyak jenis tumbuhan obat, 20-22\% yang dibudidayakan, sedangkan sekitar $78 \%$ diperoleh melalui pengambilan langsung dari hutan (Nugroho, 2010).

Pemanfaatan tumbuhan obat tradisional telah banyak dipraktekkan sejak lama oleh para orang tua maupun leluhur yang kemudian berkembang pesat dan menghasilkan sebuah kearifanlokal yang sangat khas yang dimiliki oleh masyarakat. Kearifan tersebut muncul dalam bentuk kebiasaan atau budaya pemanfaatan nilai dan khasiat dari tanaman obat, dimana kebiasaan tersebut dapat dijumpai dibeberapa negara antara lain Cina, Korea dan Jepang (Nurrani et al, 2015).Sedangkan di Benua Asia khususnya di Indonesia kebiasaan mengonsumsi obat tradisional telah lama dikembangkan dalam bentuk jamu-jamuan. Kebiasaan atau tradisi ini pertama kali oleh masyarakat Kalimantan dan dipopulerkan oleh masyarakat Jawa (Lis et al, 2015). Hal yang serupa pada kondisi yang sama juga ditemukan dan dijumpai di ujung timur Indonesia yaitu di pulau NTB dan NTT, dimana masyarakat Kabupaten Bima, Dompu dan masyarakat Kota Bima, memiliki kebiasaan mengonsumsi buah merah yang terbukti sebagai obat yang sangat mujarab (Azmin et at, 2019).

Kabupaten Bima merupakan salah satu daerah di Propinsi NTB yang memiliki 
kekayan alam melimpah terutama tumbuhan obat (Martiningsih et al, 2018). Potensi tumbuhan obat tersebut dimanfaatkan dan dikelolah oleh masyarakat di setiap Kecematan yang ada di Kabupaten Bima sebagai hasil alam yang berguna bagi kesejahteraan masyarakat (Azmin et al, 2018). Pengelolaan dan pemanfaatan berbagai tumbuhan obat tradisional oleh masyarakat pada umumnya didasarkan pada pengetahuan lokal dan kebijakan yang telah dipatuhi sebagai tradisi dan hukum adat yang diwariskan secara turun temurun (Selawa dan Citraningtyas, 2013).

Mengingat berbagai tekanan dan ancaman pada kawasan konservasi dan masih minimnya informasi serta publikasi ilmiah mengenai kandungan metabolisme sekunder tumbuhan obat tradisional, maka diperlukan penelitian yang bertujuan untuk mengkaji pemanfaatan tumbuhan yang berkhasiat obat Abubakar et al (2015). Informasi ini dapat digunakan untuk memperkuat data base bioekonservasi dan bioekologi tumbuhan obat serta menjadi acuan bagi pengelolaan kawasan berbasis kesejahteraan masyarakat dan kelestarian kehidupan.

Selain itu, masyarakat Kabupaten Bima mengunakan dan mengonsumsi tumbuhan obat sebagai obat seringkali tidak didasarkan pada pemahaman ilmiah tentang kandungan kimia dari tumbuhan obat tersebut, sehingga dalam menentukan jumlah dosis yang tepat dalam pengunaan obat tradisional tersebuthanya mengandalkan pada pengalaman dan kebiasan turun temurun (Azminet al, 2019). Untuk mengkaji secara ilmiah senyawa penting yang terdapat pada tumbuhan obat tradisional yang dapat bermanfaat terhadap kesehatan dan berfungsi sebagai obat, maka perlu adanya ekstraksi senyawa metabolit sekunder dan uji fitokimia, sehingga peneliti mengambil judul penelitian ini yaitu "Uji fitokimia dan Etnobotani Tumbuhan Obat Tradisional Berbasis Pengetahuan Lokal di Kecematan Lambitu Kabupaten Bima” yang bertujuan untuk mengetahui kandungan dan pemanfaatan tumbuhan obat Tradisional oleh Masyarakat Daerah Bima.

\section{METODE}

\section{Jenis Penelitian, Tempat dan Waktu}

Jenis penelitian ini adalah penelitian eksperimen dan pengamatan langsung di Lapangan dan Labortorium. Penelitian ini dilaksanakan selama 10 bulan. Penelitian ini dilakukan ditiga desa yaitu di desa Sambori, Desa Kuta dan Desa Teta di Kecamatan Lambitu Kabupaten Bima. Ekstraksi sampel tumbuhan dan analisis skrining fitokimia di Laboratorium Kimia STKIP Bima.

\section{Alat dan Bahan}

Alat yang digunakan antara lain parang, pisau, gunting stek, rol meter, GPS, tally sheet, kamera, kuesioner, papan data, tali rapia, koran, plastik clip ukuran $10 \times 10$ $\mathrm{cm}$, plastik klip ukuran $100 \mathrm{~cm}$ x $58 \mathrm{~cm}$, spidol permanen, alat tulis menulis, dan perlengkapan kemah.Bahan yang digunakan dalam penelitian ini adalah peta kawasan daerah Bima, adalah 19 jenis tumbuhan obat sebagai sampel dan bagian tumbuhan yang dipakai untuk uji adalahakar, batang, daun, umbi, rimpang dan kulit. $\mathrm{NaOH}, \mathrm{HCl}$, $\mathrm{H}_{2} \mathrm{SO}_{4}$, aquades, heksana, kloroform, asam klorida, dan etanol

\section{Prosedur Pengumpulan Data Penelitian}

Metode pengumpulan data yang digunakan yaitu kombinasi teknik survei lapangan (observasi), teknik wawancara secara mendalam (in depth interview), dan teknik kuesioner. Informan ditentukan berdasarkan keterangan dari tokoh masyarakat adat, kepala suku, kepala desa, 
kepala kampung, dan sumber terpercaya lainnya yang mengetahui hal-hal yang berkaitan erat dengan kegiatan yang akan dilaksanakan. Responden sebagai kunci dan pemanfaat tumbuhan obat sebanyak 20 orang yang berasal dari 3 Desa di sekitar Hutan Kecematan Lambitu.

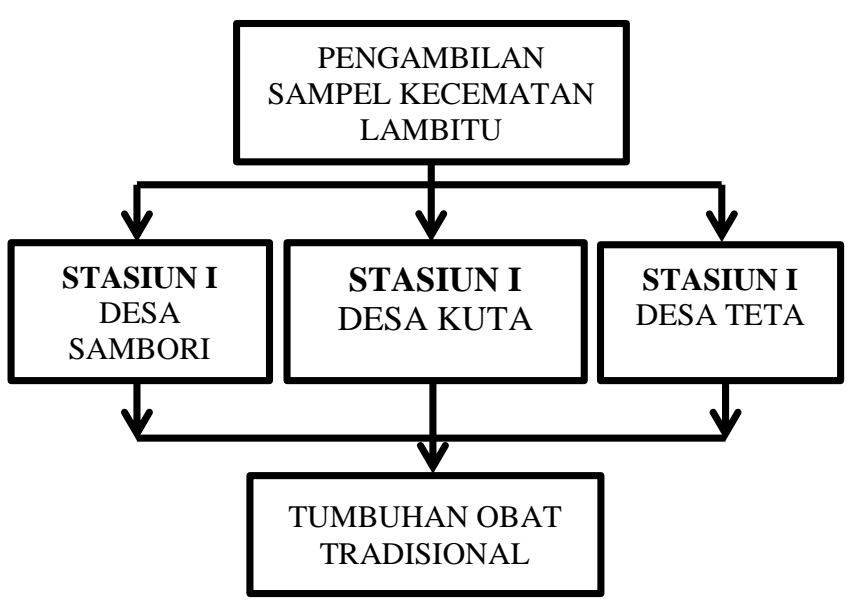

Gambar 1. Rancangan Penelitian

\section{Analisis Data}

Identifikasi herbarium untuk jenisjenis yang belum diketahui di Laboratorium Kimia dan Ekstraksi sampel tumbuhan serta analisis fitokimia di Laboratorium Biologi STKIP Bima. Data potensi, jenis, manfaat tumbuhan obat berikut hasil analisis laboratorium ditabulasi dan interaksi masyarakat dianalisis secara diskriptif

\section{Uji Skrining Fitokimia}

\section{Tahapan Uji senyawa alkaloid}

Uji alkaloid dilakukan dengan metode Mayer dan Wagner. Sampel sebanyak $3 \mathrm{~mL}$ dimasukan dalam cawan porslen kemudian ditambahkan $5 \mathrm{~mL} \mathrm{HCl} 2 \mathrm{M}$ dan $5 \mathrm{~mL}$ aquades, kemudian dipanaskan di atas penangas air selama 5 menit. Dinginkan sampel pada temperatur kamar setelah itu disaring. Filtrat yang diperoleh dibagi 3 . Filtrat 1 sebagai kontrol, filtrat 2 ditambah pereaksi Mayer, reaksi positif jika terbentuk endapan menggumpal berwarna putih atau kuning.

\section{Tahapan Uji senyawa flavonoid.}

Ekstrak sampel diuapkan sebanyak 5 $\mathrm{mL}$, dicuci menggunakan heksana sampai terlihat jernih. Sisa ekstrak sampel dimasukan dalam $20 \mathrm{~mL}$ etanol untuk dilarutkan, kemudian disaring. Setelah di saring kemudian dibagi menjadi 3 bagian, bagian 1 dipanaskan menggunakan penangas air, jika terjadi perubahan warna pada sampel dengan menunjukan warna hijau kekuningkuningan menunjukkan adanya senyawa flavonoid. Bagian 2 ditambahkan larutan $\mathrm{NaOH} 10 \%$, Jika terajdi warna biru-ungu menunjukkan adanya senyawa flavonoid.

\section{Uji steroid dan terpenoid.}

Sebanyak $5 \mathrm{~mL}$ sampel dimasukkan dalam gelas kimia, kemudian ditambah $5 \mathrm{~mL}$ kloroform dan diaduk sampai rata. Selanjutnya ditambahkan pereaksi $\mathrm{H}_{2} \mathrm{SO}_{4}$ pekat. Apabila terbentuk warna merah menunjukkan adanya steroid dan terpenoid. 


\section{Uji saponin.}

Sebanyak $5 \mathrm{~mL}$ sampel dimasukkan ke dalam tabung reaksi, lalu ditambahkan 15 $\mathrm{mL}$ air panas, didinginkan kemudian dikocok kuat-kuat selama 10 sampai 20 detik. Jika terbentuk busa setinggi $1-10 \mathrm{~cm}$ yang stabil tidak kurang dari 10 menit dan tidak hilang dengan penambahan 1 tetes asam klorida 2 M menunjukkan adanya senyawa saponin

\section{HASIL DAN PEMBAHASAN}

\section{Letak Geografis dan Ketinggian Tempat} Kecematan Lambitu

Topografi Wilayah Kecematan mempunyai wilayah topografi yang bervariasi berupa perbukitan, pegunungan, lembah dan sungai dengan ketinggian 20003500 meter dpl (termasuk ketinggian dari ketinggian Desa Sambori, Desa Kuta, dan Desa Teta) (Tabel 1 dan Gambar 2) serta tidak mempunyai wilayah pantai. Secara umum keadaan Topografi Wilayah wilayah didominasi oleh bukit-bukit dan gununggunung yaitu sekitar $90 \%$ dari luas wilayah Kabupaten Bima, sedangkan yang datar hanya 10\% (Miftahulet al, 2016).

Lambitu Kabupaten Bima pada umumnya

Tabel 1. Letak Geografis dan Ketinggian Tempat Kecematan Lambitu

\begin{tabular}{clll}
\hline No & Nama Desa & Letak Geografis & $\begin{array}{l}\text { Ketinggian } \\
\text { tempat(m dpl })\end{array}$ \\
\hline 1. & Desa Sambori & $0,5^{0} 01^{\prime} 050^{\prime \prime} \mathrm{LT}$ & 3500 \\
& & $118^{0} 500^{\prime} 338^{\prime \prime} \mathrm{BT}$ & \\
2. & Desa Kuta & $0,5^{0} 43.993$ ' LS & 2250 \\
& & $118^{0} 64.805 \mathrm{BT}$ & \\
3. & Desa Teta & $0,5^{0} 55.955^{\prime \prime} \mathrm{LS}$ & 2200 \\
\hline
\end{tabular}

(Badan Pusat Statistik, 2012)

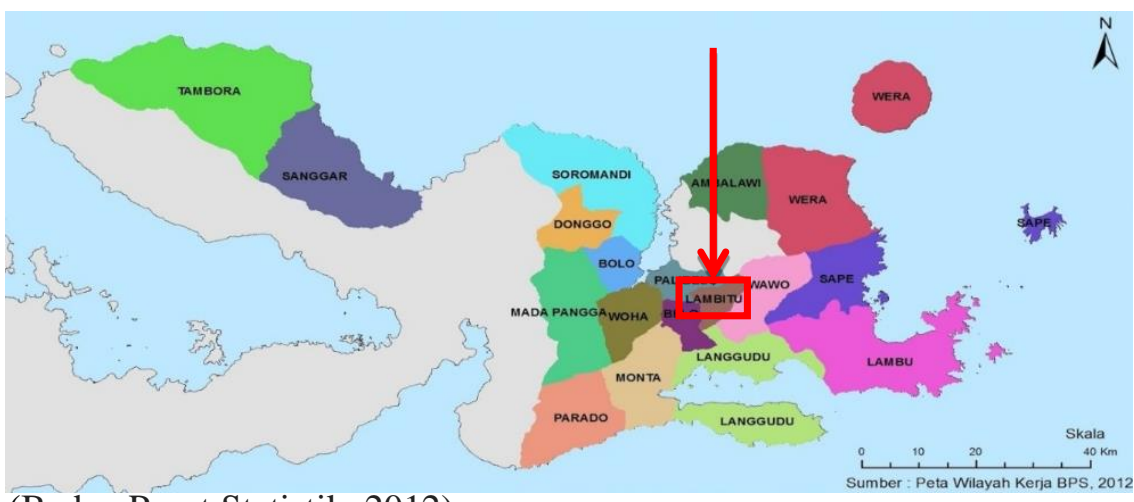

(Badan Pusat Statistik, 2012)

Gambar 2. Peta Kabupaten Bima, sedangkan yang diberi anak panah berwarna merah adalah Kecematan Lambitu

\section{Hasil Identifikasi Jenis Tumbuhan Obat}

Berdasarkan hasil wawancara dengan 20 responden diketahui bahwa terdapat 19 jenis tumbuhan obat yang umum dimanfaatkan oleh masyarakat kecamatan
Lambitu (Tabel 2). Umumnya tumbuhan tersebut diambil disekitar hutan dan gunung, maupun di pekarangan rumah, ada juga masyarakat yang membudidayakannya. Adapun perbanyakan tumbuhan obat melalui 
penanaman langsung yaitu perbanyakan pada batang, tunas dan ada pula yang melalui biji. Hal ini seseuai dengan data yang diperoleh dari Miftahulet al, (2016), yang menyatakan bahwa daerah Kecematan Lambitu Kabupaten Bima adalah daerah yang beriklim tropis yang bersuhu dingin karena terdiri dari pegunungan, dan bukitbukit yang saling sambung-menyambung antara satu sama lain.

Pemahaman masyarakat daerah Bima dalam memanfaatkan tumbuhan obat terdiri atas tiga tahap antara lain yaitu cara mengambil tumbuhan obat sebagi bahan untuk membuat ramuan (dalam bahasa daerah Bima adalah jamu atau lo 'i pa'i), cara meracik atau membuat jamu, dan waktu untuk mengkonsumsi racikan jamu.
Masyarakat kecematan Lambitu umumnya mengolah tumbuhan obat tradisional dengan cara direbus. Misalnya pada tumbuhan Kersen, cara pengolahannya adalah daunnya direbus. Menurut Maridi (2015) cara pengolahan direbus sangat mudah dan sangat efektif karena masyarakat pada umunya lebih suka tumbuhan tersebut diolah menjadi air rebusan dibandingkan mengkonsumsi secara langsung. Selain itu, proses penyembuhannya lebih cepat karena langsung diproses dalam metabolisme tubuh (Suhartini, 2009).Pemanfaatan tumbuhan sebagai obat tergantung dari kandungan yang ada dalam bagian tumbuhan yang digunakan untuk menyembuhkan penyakit (Ariefa, 2013)

Tabel 2. Jenis Tumbuhan Obat Tradisional Yang digunakan oleh Masyarakat Kecematan Lambitu Kabupaten Bima

\begin{tabular}{|c|c|c|c|c|c|}
\hline $\begin{array}{c}\text { Sampel } \\
\text { Tumbuhan }\end{array}$ & Nama Ilmiah & $\begin{array}{l}\text { NamaDaer } \\
\text { ah Bima }\end{array}$ & Habitus & $\begin{array}{c}\text { Kegunaan dan Cara } \\
\text { Meramu }\end{array}$ & Gambar \\
\hline Okra & $\begin{array}{c}\text { Abelmosshus } \\
\text { esculentus }\end{array}$ & Skadi rido & Perdu & $\begin{array}{l}\text { Obat penyakit gula dan } \\
\text { kolestrol: daun, batang } \\
\text { dan buah tanaman di } \\
\text { potong kemudia ditumbuk } \\
\text { sampai halus kemudian } \\
\text { direbus lalu diminum }\end{array}$ & \\
\hline
\end{tabular}

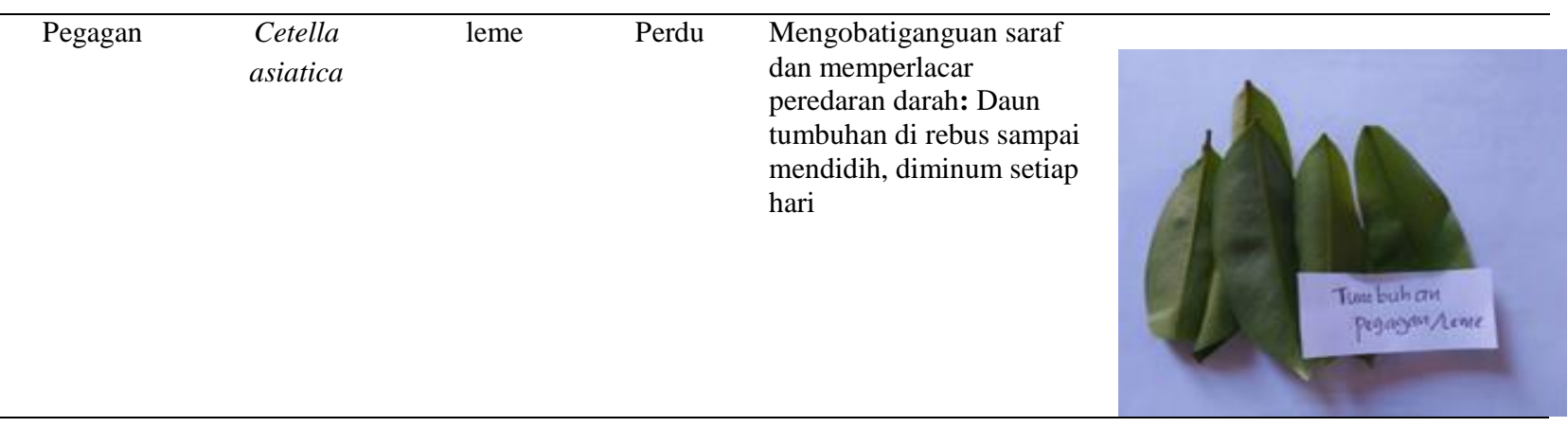




\begin{tabular}{|c|c|c|c|c|c|}
\hline Jombang & Taraxacum & minan & Perdu & $\begin{array}{l}\text { Mengobati penyakit } \\
\text { wasirdaun yang muda di } \\
\text { ambil kemudian direbus } \\
\text { sampai berwarna lalu } \\
\text { diminum }\end{array}$ & 8 \\
\hline Sukun & Artocarpus & Karara & Pohon & $\begin{array}{l}\text { Obat luka pada lambung } \\
\text { dan kanker payudara: } \\
\text { Batang di keringkan dan } \\
\text { di rebus sampai berwarna, } \\
\text { kemudian di dinginkan } \\
\text { setelah itu diminum pagi } \\
\text { dan sore hari }\end{array}$ & [ \\
\hline Adas sowa & $\begin{array}{c}\text { Anethumgrave } \\
\text { olens. }\end{array}$ & Musi & Herbal & $\begin{array}{l}\text { Obat pegal-pegal: daun } \\
\text { dan bungan di haluskan, } \\
\text { setelah itu dicampurkan } \\
\text { dengan air hangat } \\
\text { kemudian dioleskan pada } \\
\text { tubuh yang pegal }\end{array}$ & \\
\hline $\begin{array}{c}\text { Kembang } \\
\text { Bulan }\end{array}$ & $\begin{array}{c}\text { Tithonia } \\
\text { diversifoliu }\end{array}$ & binahong & Pohon & $\begin{array}{l}\text { Obat untuk memperlancar } \\
\text { peredaran darah: semua } \\
\text { bagian tumbuhan di } \\
\text { ambil, di keringkan setalh } \\
\text { itu di tumbuk harus, ada } \\
\text { yang di rebus dan ada } \\
\text { yang dibuat seperti kapsul } \\
\text { supaya tetap awet untuk } \\
\text { dikonsumsi secara } \\
\text { kontinyu }\end{array}$ & \\
\hline $\begin{array}{c}\text { Kecubung } \\
\text { gunung }\end{array}$ & Brugmania & katleya & Herbal & $\begin{array}{l}\text { Mengobati rasa nyeri: } \\
\text { daun dan buah di rebus } \\
\text { secara bersama dalam } \\
\text { satu wadah, kemudian } \\
\text { diminum secara terus } \\
\text { menerus sampai rasa } \\
\text { nyeri pada bagian tubuh } \\
\text { hilang }\end{array}$ & \\
\hline
\end{tabular}




\begin{tabular}{|c|c|c|c|c|}
\hline Jarak Pagar & $\begin{array}{c}\text { Jatropha } \\
\text { curcas }\end{array}$ & Tatanga & Perdu & $\begin{array}{l}\text { Mengobati Deman atau } \\
\text { panas dingin pada tubuh: } \\
\text { selurus bagian tumbuhan } \\
\text { di ambil dan direbus } \\
\text { sampai berwarna sehingga } \\
\text { kandungannya tercampur } \\
\text { menjadi satu lalu } \\
\text { diminum setiap hari }\end{array}$ \\
\hline
\end{tabular}

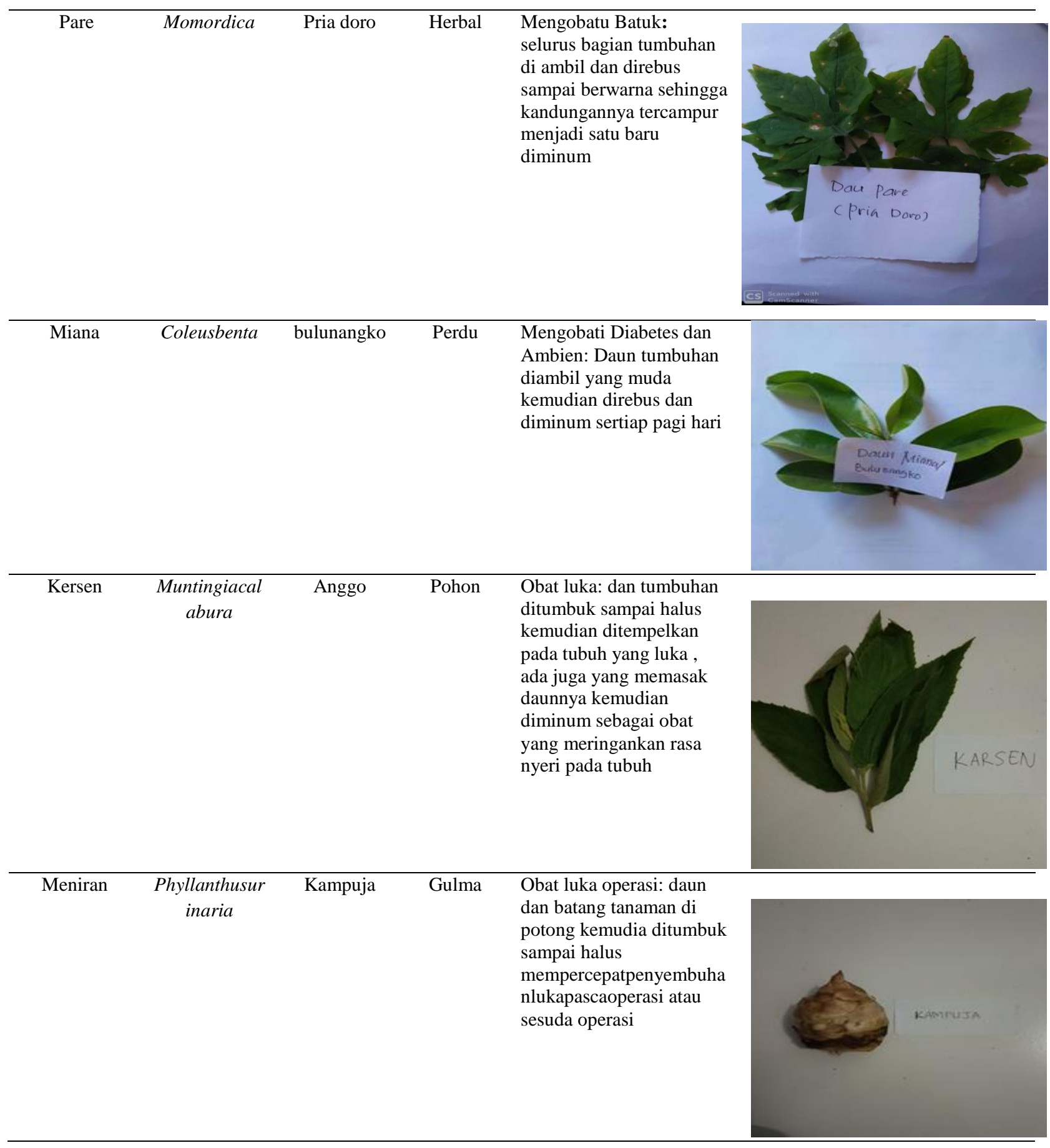




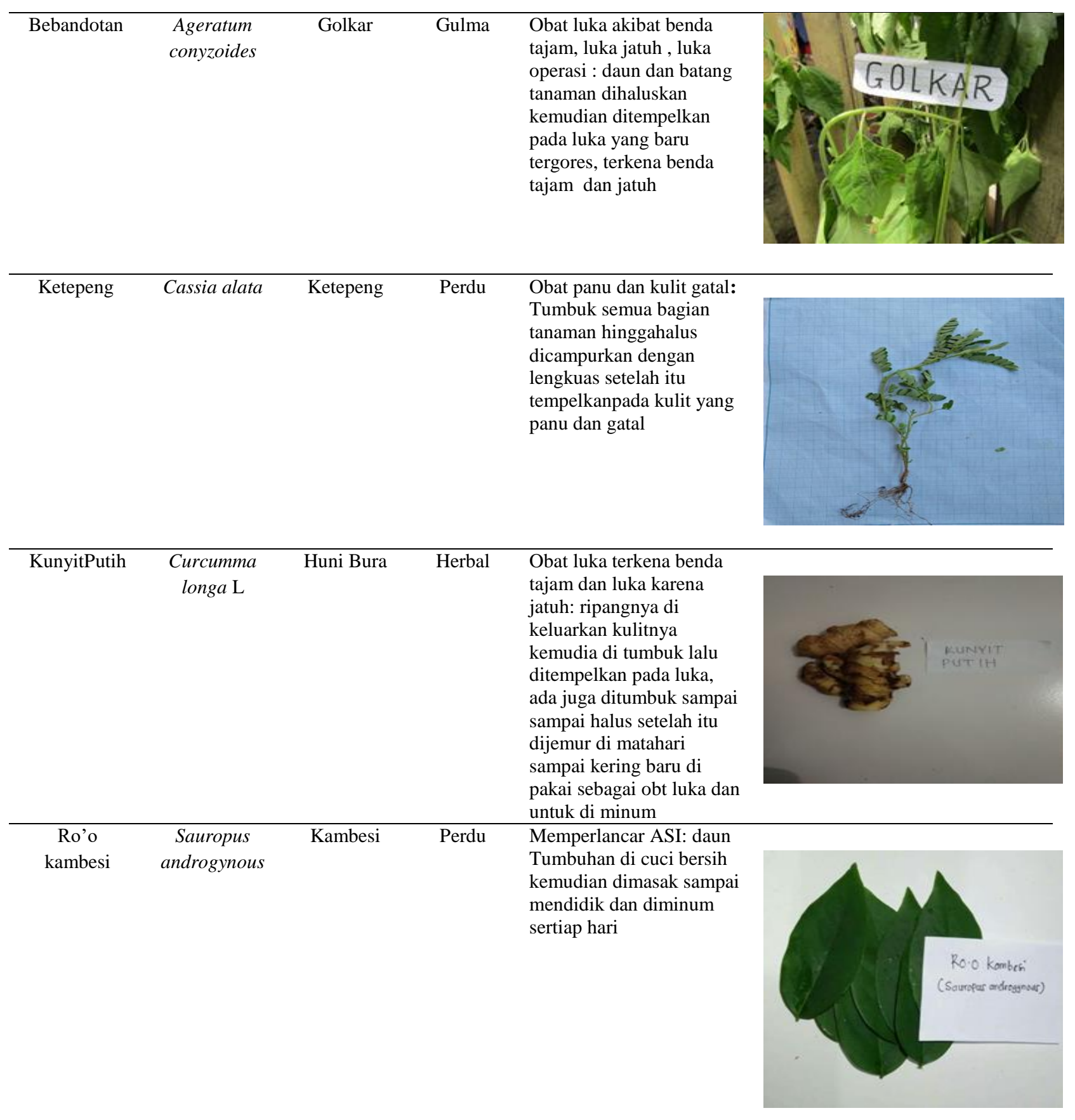

\begin{tabular}{|c|c|c|c|c|}
\hline Karara & $\begin{array}{c}\text { Artocarpus } \\
\text { communis }\end{array}$ & Karara & Pohon & $\begin{array}{l}\text { Mengobati diabetes: daun } \\
\text { Tumbuhan diambil yang } \\
\text { muda dan dicuci bersih } \\
\text { kemudian dimasak dan } \\
\text { diminum sertiap hari }\end{array}$ \\
\hline
\end{tabular}




\begin{tabular}{|c|c|c|c|c|}
\hline Jambu & $\begin{array}{l}\text { Psidium } \\
\text { guajava }\end{array}$ & Jambu doro & Perdu & $\begin{array}{l}\text { Mengobati diare: daun } \\
\text { dan tunas di ambil } \\
\text { kemudian di cuci bersih } \\
\text { setelah itu lansung } \\
\text { dimakan, ada juga yang } \\
\text { mengeringkan daunya } \\
\text { untuk dibuatkan kapsul } \\
\text { supaya tetap tahan lama } \\
\text { dan bias dikonsumsi lebih } \\
\text { lama }\end{array}$ \\
\hline
\end{tabular}

\begin{tabular}{|c|c|c|c|c|}
\hline Kana,a & $\begin{array}{c}\text { Euphorbia } \\
\text { hirta }\end{array}$ & Kana,a & Pohon & $\begin{array}{l}\text { Mengobai Sesak napas: } \\
\text { akar, batang dan daun di } \\
\text { ambil kemudian direbus } \\
\text { lalu di minum setiap hari }\end{array}$ \\
\hline
\end{tabular}

\section{Hasil Indentifikasi Jenis Habitus dan Pemanfaatannya}

Berdasarkan data hasil observasi dan wawancara bahwa masyarakat Kecematan Lambitu yang tinggal dan bermukim disekitar pegunungan pada umumnya telah mengetahui dan memanfaatkan berbagai jenis tumbuhan dan tanaman obat tradisonal untuk kebutuhan kehidupan sehari-hari mereka serta ada juga yang mengunakan tumbuhan obat tradisional untuk dijual dalam bentuk jamu atau dalam bahasa Daerah Masyarakat Bima (lo'i pa'i) untuk membantu peningkatan perekonomian mereka yang hingga kini masih dapat ditemukan dan terus dilestarikan khususnya pada wilayah pedesaan. Adapun jenis penyakit yang diobati cukup bervariasi dari alergi dan luka ringan, penyakit dalam kronis hingga penyakit akibat kekuatan mistik. Karakteristik tumbuhan obat dan cara pemanfaatannya pun sangat khas pada masing-masing lokasi penelitian, sesuai pengetahuan dan pengalaman yang dimiliki serta kearifan lokal setempat (Azmin et al, 2019).

Hasil identifikasi tumbuhan obat yang dimanfaatkan sebagai obat ada sebanyak 19 jenis tumbuhandi keseluruhan kecamatan lambitu (Desa Sambori, Kuta dan Teta). Umumnya masyarakat kecamatan lambitu mengelola dan memanfaatkan berbagai jenis tumbuhan obat, dari berbagai habitus seperti pohon, perdu, herbal dan gulma, sedangkan pada bagian tumbuhannya misalnya pada kulit, daun, bunga, akar dan batang dan berdasarkan hasil wawancara di lapangan bahwa masyarakat kecamatan lambitu paling banyak Perdu dan pohon merupakan habitus tumbuhanyang paling banyak dimanfaatkan sebagai bahan pengobatan dalam obat tradisional yaitu $35 \%$, diikuti oleh pohon $30 \%$, herbal $25 \%$ dan gulma $10 \%$. Bagian tumbuhan yang banyak dimanfaatkan sebagai ramuan adalah daun yaitu $40 \%$, rimpang $28 \%$ buah $12 \%$, batang $8 \%$, Akar $8 \%$ dan lendir sebayak 4\% (Gambar 3). Pernyataan ini didukung dengan hasil 
penelitian Nurul (2018) bahwa pohon dan perdu merupakan kelompok famili dengan spesies terbanyak yang dimanfaatkan sebagai obat tradisonal.

Menurut Nurrani et al (2015) mengatakan bahwa pemanfaatan bagian daun dari tumbuhan obat ini merupakan salah satu upaya konservasi terhadap tumbuhan obat tradisional. Penggunaan daun sebagai obat tidak berdampak buruk bagi kelangsungan hidup tumbuhan. Bagian tumbuhan yang perlu dibatasi penggunaannya dalam pengobatan adalah bagian akar, batang, kulit kayu dan umbi, karena penggunaan bagian-bagian tumbuhan ini dapat langsung mematikan tumbuhan.

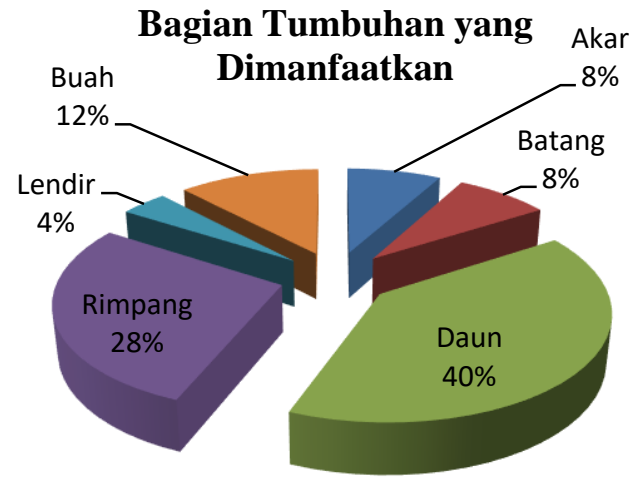

\section{Hibitus Tumbuhan Obat yang Dimanfaatkan}

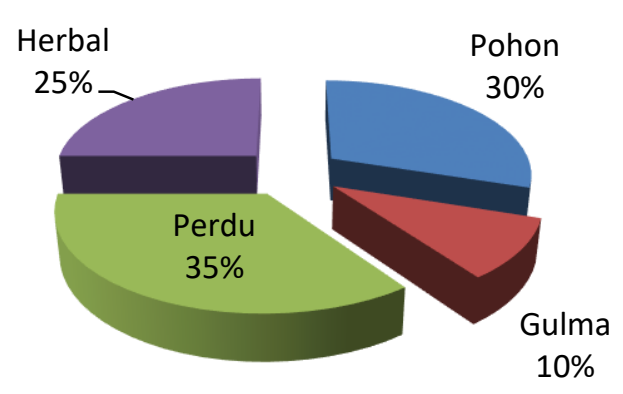

Gambar 3. Jenis tumbuhan obat yang digunakan dan bagian tumbuhan yang diambil untuk dijadikan obat oleh Masyarakat Kecamatan Lambitu

Hasil Uji Skerening Fitokimia Tumbuhan

Hasil uji fitokimiadari 19 tumbuhan obat yang digunakan terdapat 18 jenis tumbuhan yang mengandung flavonoid yang ditandai dengan tanda plus (+), 16 jenis tumbuhan yang mengandung alkaloid, 15 tumbuhan yang mengandung steroid sedangkan pada terpenoid hanya terdapat 11 tumbuhan, 14 tumbuhan yang mengandung saponin dan 13 tumbuhan yang mengandung tanin (Tabel 2 dan Gambar 2). Senyawa fitokimia tumbuhan di atas memliki efek yang berbeda-beda salah satu contohnya flavonoid. Masyarakat kecamatan Lambitu kebanyakan menggunakan tumbuhan ini sebagai obal luka pada kulit. dari penjelasan lain mengatakan bahwa senyawa flavonoid berfungsi sebagai obat luka, jika berkombinasi dengan saponin secara bersama (Fitriah et al, 2017). Hal juga didukung dengan hasil penelitian Indranila dan Maria, (2015) yang mengatakan bahwa senyawa flavonoid befungsi sebagai obat bagi tubuh manusia.

Senyawa Flavonoid memiliki efek berupa pemicu sistem syaraf, menaikkan tekanan darah, mengurangi rasa sakit, antimikroba, obat penenang, obat penyakit jantung dan antidiabetes (Azmin et al, 2019). Senyawa flavonoid memiliki efek antihipertensi dan mencegah pendarahan pada kulit (Rohyaniet al, 2015), sebagai antioksidan atau penghambat radikal bebas. Selain itu senyawa flavonoid bisa 
berkombinasi dengan saponin secara bersamayang bermanfaat sebagai penurun kadar gula darah (Fitriah et al, 2017)

Tabel 2. Hasil uji fitokimia Tumbuhan Obat Tradisional Masyarakat Kecematan Lambitu Kabupaten Bima

\begin{tabular}{lccccc}
\hline \multirow{2}{*}{$\begin{array}{c}\text { Sampel Tumbuhan } \\
\text { Obat }\end{array}$} & Flavonoid & Alkaloid & $\begin{array}{c}\text { Steroid/ } \\
\text { Terpenoid }\end{array}$ & Saponin & Tanin \\
\hline Artocarpus & & & & + & + \\
Abelmosshus esculentus & + & + & $-/-$ & - & + \\
Taraxacum & + & + & $+/+$ & + & - \\
Cetella asiatica & + & + & $-/+$ & + & + \\
Anethumgraveolens & + & + & $+/+$ & + & - \\
Tithonia diversifoliu & + & - & $+/+$ & + & + \\
Brugmania & + & + & $+/+$ & + & + \\
Calontropis gigantean & + & + & $+/+$ & + & - \\
Momordica & + & + & $+/-$ & - & + \\
Coleusbenta & - & - & $-/-$ & + & - \\
Muntingiacalabura & + & + & $+/+$ & + & + \\
Phyllanthusurinaria & + & + & $+/+$ & + & - \\
Ageratum conyzoides & + & + & $-/-$ & + & + \\
Cassia alata & + & + & $+/+$ & + & - \\
Curcumma longa L & + & + & $+/+$ & + & + \\
Sauropus androgynous & + & + & $+/-$ & - & + \\
Artocarpus communis & + & + & $+/+$ & + & + \\
Psidium guajava & + & + & $+/-$ & - & + \\
Euphorbia hirta & + & + & $+/-$ & - & + \\
\hline
\end{tabular}

Keterangan: +Mengandung senyawa obat

- Tidak mengandung senyawa obat

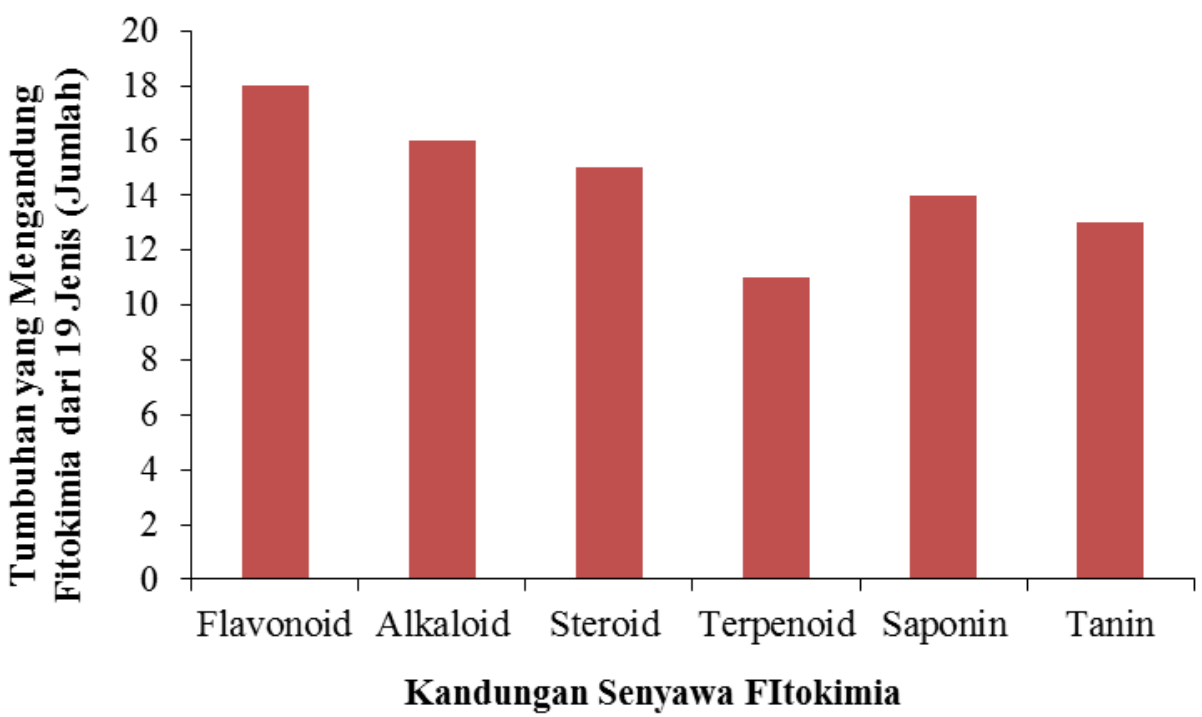

Gambar 4. Hasil uji fitokimia Tumbuhan Obat Tradisional Masyarakat Kecematan Lambitu Kabupaten Bima 


\section{KESIMPULAN}

Terdapat 19 jenis tumbuhan obat yang digunakan oleh Masyarakat Kecamatan Lambitu (Desa Sambori, Kuta dan Teta) dan yang paling banyak dimanfaatkan adalah pada bagian daun sedangkan habitusnya pada jenis pohon dan gulma.Tumbuhan obat tersebut untuk mengobati berbagai penyakit yaitu dengan cera meraciknya dengan kombinasi beberapa jenis tumbuhan. Hasil analisis kandungan senyawa menunjukan bahwa 19 jenis tumbuhan mengandung senyawa seperti Flavonoid, Alkaloid, Steroid, Terpenoid, Saponin dan Tanin.

\section{DAFTAR PUSTAKA}

Ariefa, P.Y. (2013). Kearifan Lokal Penggunaan Tumbuhan Obat Oleh Suku Lembak Delapan Di Kabupaten Bengkulu Tengah, Bengkulu. Prosiding Semirata FMIPA Universitas Lampung.

Azmin, N., \& Rahmawati, A. (2019). Kearifan Lokal Dalam Pemanfaatan Tumbuhan Obat Tradisional Oleh Masyarakat Daerah Bima. In Prosiding Seminar Nasional II APPPI NTB 2018. 1, (1).

Abubakar, S. K., Zainuddin, L dan $\mathrm{MOH}$. (2015). Inventory of medicinal plants and local wisdom of Bune Ethnic in utilizing plant medicine in Pinogu, Bonebolango District, Gorontalo Province. Prosiding Semnas Biodiv Indon 1(1): 78-84.

Fitriah., Mappiratu., dan Prismawiryanti. (2017). Uji Aktivitas Antibakteri Ekstrak Daun Tanaman Johar (Cassia siamea Lamk.) Dari Beberapa Tingkat Kepolaran Pelarut. Jurnal KOVALEN, 3(3): 242-251.
Indranila dan Maria Ulfah. (2015). Uji Aktivitas Antioksidan Ekstrak Etanol Daun Karika (Caricapubescens) Dengan Metode DPPH Beserta Identifikasi Senyawa Alkaloid, Fenol Dan Flavonoid. Prosiding Seminar Nasional Peluang Herbal Sebagai Alternatif Medicine. ISBN: 978-60219556-2-8.

Lis Nurrani, Supratman Tabba \& Hendra S. Mokodompit. (2015). Local Wisdom in the Utilization of Medicine Plants by Community Around Aketajawe Lolobata National Park, North Maluku Province. Jurnal Penelitian Sosial dan Ekonomi Kehutanan. 12(3): 163-175.

Maridi. (2015). Mengangkat Budaya dan Kearifan Lokal dalam Sistem Konservasi Tanah dan Air. Prosiding Seminar Nasional XII Pendidikan Biologi FKIP UNS.

Martiningsih, Nasir M., Azmin N. (2018) Inventarisasi Berbagai Jenis Tumbuhan Obat Tradisional DiKecamatan Wawo Sebagai Kearifan Lokal Masyarakat Bima. Oryza Jurnal Pendidikan Biologi. 7(2): 8-13.

Miftahul, J dan Muhammad Saleh Madjid. (2016). Kecamatan Madapangga Kabupaten Bima (2001-2014). Jurnal Pemikiran Pendidikan Dan Penelitian Kesejarahan. 3(2).

Nurul, P.P. (2018). Local wisdom of Dayak Agabag medicinal plants in Nunukan Regency East Kalimantan. Jurnal AGRIFOR. 12(1): 1412-6885.

Nugroho, I.A. (2010). Lokakarya Nasional Tumbuhan Obat Indonesia.Asian Pacific Forest Genetic Resources Programme Kerjasama Pusat Penelitian dan Pengembangan 
Peningkatan Produktivitas Hutan. Jurnal Apforgen news Letter. 2(2): 12.

Nurrani, L. dan Tabba, S. (2015). Kearifan suku Togutil dalam konservasi Taman Nasional Aketajawe di wilayah hutan Tayawi Provinsi Maluku Utara. Prosiding Ekspose Hasil-Hasil Penelitian Balai Penelitian Kehutanan Manado. Manado:Balai Penelitian Kehutanan Manado.pp.227-244.

Rahayu, M. Siti Sunarti, Diah Sulistiarini., Suhardjono P. (2006). Pemanfaatan Tumbuhan Obat secara Tradisional oleh Masyarakat Lokal di Pulau Wawonii, Sulawesi Tenggara. Jurnal Biodiversitas. 7(3): 245-250.

Rohyani, I.S., Aryanti, E., Suripto, (2015). "Kandungan Fitokimia Beberapa
Jenis Tumbuhan Lokal yang sering dimanfaatkan sebagai Bahan Baku Obat di Pulau Lombok", Pros. Sem. Nas. Masy. Biodiv. Indon. 1(2): 388391.

Suhartini. (2009). Kajian Kearifan Lokal Masyarakat Dalam Pengelolaan Sumberdaya Alam Dan Lingkungan. Prosiding Seminar Nasional Penelitian, Pendidikan dan Penerapan MIPA, Fakultas MIPA, Universitas Negeri Yogyakarta.

Selawa, W., Runtuwene, M.R.J. \& Citraningtyas, G. (2013). Kandungan flavonoid dan kapasitas antioksidan total ekstrak etanol daun binahong (Anredera cordifolia (Ten.).Jurnal Ilmiah Farmasi Universitas Sam Ratulangi, 2(1): 18-22. 